\title{
THE PURSUIT OF PRESTIGE: THE DISTRIBUTION OF TALENTED STUDENTS IN CHILE'S UNIVERSITIES
}

\author{
CARlos H. WÖRner*
}

Recebido: ago. 2010

Aprovado dez. 2010

\begin{abstract}
*Doctor en Física. Profesor Titular de la Facultad de Ciencias, Pontificia Universidad Católica de Valparaíso.
Chile. E-mail cworner@ucv.cl
\end{abstract}

Resumo: Prestígio é um capital valorizado por instituições acadêmicas. Embora seja difícil de medir ou mesmo de estabelecer os seus componentes, não há dúvidas de que um corpus de estudantes talentosos é um dos ativos das instituições de ensino superior. Para a admissão dos alunos nas universidades do Chile, um sistema de avaliação nacional é utilizado e, portanto, as universidades concorrem para captar os melhores alunos. Além disso, existem subsídios financeiros estatais associados a esse atributo. $\mathrm{O}$ uso deste indicador de transferência financeira como um meio de medir esta parte da "riqueza" acadêmica das instituições é proposto. Ao utilizar o conhecido índice de Gini, a sua distribuição é analisada. Para efeito de comparação, também propõe-se o uso de outro indicador de "riqueza" com base nos resultados oficiais de um processo de acreditação nacional. Os resultados mostram um sistema claramente tendencioso medido pelos dois parâmetros mencionados, sem qualquer correlação significativa entre si. Possíveis causas desse comportamento são discutidos

Palavras-chave: Educação Superior no Chile. Índice de Acreditação, Indice de Gini.

\section{A BUSCA PELO PRESTÍGIO: A DISTRIBUIÇÃO DE ESTUDANTES TALENTOSOS NAS UNIVERSIDADES DO CHILE}

Abstract: Prestige is a valued capital for academic institutions. Although it is difficult to measure it or even to establish its components, there are no doubts that a talented corpus of students is one of the assets of higher education institutions. For students' admission in Chilean universities, a national grading system is used and therefore, universities compete in capturing the best students. In addition, there are state financed subsidies associated to this attribute. The use of this financial transfer indicator as a mean to measure this portion of academic "wealth" of the institutions is proposed. By using the well known Gini index, its distribution is analyzed. For the sake of comparison, we also propose the use of another "wealth" indicator based on the official results of a national accreditation process. The results show a clearly biased system measured by the two before mentioned parameters with no significant correlation within them. Possible causes for this behavior are discussed.

Key words: Chilean higher education. Accreditation index. Gini index.

\section{INTRODUCTION}

One of the strategic objectives of the University of Chile- the oldest institution in Chilean higher education- is: "Ser reconocida como la universidad que 
convoca y forma los talentos jóvenes más brillantes"'. This declarative objective sometimes does not appear explicitly expressed in some university formal documents, but certainly it is an appreciated attribute of this type of institutions.

Certainly, a subset of the category we call "prestige", is the academic assets of its incoming students. It is not our purpose to discuss in this note the whole theme of excellence or prestige. A recent paper of Cyrene and Grant (2009) proposes a methodology that pretends to describe and quantify the factors that influence the prestige using as a case Canadian universities. With this declared restriction, we will study the distribution of students' academic wealth according to the capture of state subsidies associated to this attribute.

For the sake of introduction, let us mention the more cited index of income inequality, that is, the Gini index (GINI, 1921) widely applied to the distribution of economic wealth. This distribution measured in different countries is a subject matter closely related to equality (or inequality) into each one of these societies. Obviously, it is not only an academic topic. It touches current society's issues such as poverty, prosperity and in a last term, the society's sustainability. In similar terms, apart from economy, the determination of the degree of concentration of a variable also appears in ecology, transport engineering, geography, etc.

On the educational side, Gini index has been used to describe class barriers in higher education (LYNCH; O'RIORDAN, 1998) and also it has been employed to measure educational inequality, mainly by mean of years of scholarly (THOMAS; WANG; FAN, 2001; DIGDOWISEISO, 2010).

In this work, a variable directly related to the "quality" of the incoming students is proposed to measure this aspect of academic wealth. For this effect, we will use the amount of government's money distributed according to the captured student's scores of the national grading test. Using this indicator we can measure the degree of concentration of this academic capital. Also, for the purpose of comparison we built a new indicator based on the results of the national accreditation process.

We will restrict our considerations to universities in Chile. As it has been recently remarked, Chile is one of the more liberal countries in higher education (BERNASCONI; ROJAS, 2004; BRUNNER et al, 2005; BRUNNER, 2008, 2009), and therefore an analysis of this variable can illuminate controversial issues related to the transition from a regulated to unregulated market. Incidentally, the above mentioned papers cleverly expose the present situation on the Chilean system of higher education.

\footnotetext{
1 "Being recognized as the university that summons and shapes the brightest young talents."
} 
As an introduction, we will begin this paper with a brief description of the Chilean system of higher education. Afterward, we will present the results of our analysis and compare the data with another parameter based on the accreditation results. Finally, we will discuss some hypothesis on the observed "academic" inequality in the Chilean higher education system. An appendix is added with the essential statistical meaning of the Gini index.

\section{THE CHILEAN SYSTEM OF HIGHER EDUCATION}

The Chilean system of higher education is composed of technical centers (CFT by its Spanish initials, roughly equivalent to two-year colleges), professional institutes (IP, four-year professional colleges) and universities. One type of classification, useful for our present purposes, is to use the degree of state financial support to each university budget. A subset of universities, labeled "traditional", receives direct support and the others do not receive direct state support (these last ones are usually called "private"). It is interesting to note that this classification does not refer to the property of the institutions. Furthermore, Chile is a unitary country and the relationship between the higher education system and the government is mediated by the Ministry of Education. There is a special association between the traditional universities and the government through the Council of University Presidents (CRUCH: Consejo de Rectores de Universidades Chilenas). For different types of classification of Chilean universities, it is possible to consult the above mentioned paper of Brunner et al (2005) and a report of the Central Bank of Chile (RAPAPORT; BENAVENTE; MILLER, 2004). Recently, OECD delivered a sound report on Chilean higher education (THE WORLD BANK, 2009).

The universities belonging to CRUCH prepare each year a national examination for high school candidates to gain admittance to the universities in a manner similar to the SAT-test in USA. The results of this examination are mandatory, and must be considered for admittance in a university belonging to the CRUCH. Also, they are not mandatory but they are usually considered for access to the other Chilean universities.

In the time span this paper considers, two different questionnaires were applied in different time intervals. The first national test (until 2003) was named Aptitude Scholar Test (PAA by its Spanish initials). From 2004 on, a new measurement test is applied, named Selection University Test (PSU by its Spanish initials). These two examinations differ in a deep qualitative approach: the first one intent to measure altitudinal modes of learning and the last pretend 
to measure acquired high school knowledge. According, we will present our results following these two calendar epochs.

Going to financial matters, the state directly subsidies all universities belonging to the CRUCH (it is a subsidy to the supply, see i.e. WÖRNER, 2009) and also the government uses a financial incentive to the demand. This last one is named the "indirect state support" (AFI in Spanish). It consists of an amount of money transferred to all the universities (not only the traditional ones) according to its capacity to capture the best students ranked by the PAA (until 2003) and PSU (from 2004 on). The rationale under this procedure is that the best students (that is, the students with better scores in these tests) will choose the best universities. Therefore, this subsidy is directly related to the quality of the university as subjectively perceived by the customers (incoming students and/or their families).

Although it is controversial that this incentive is effectively a quality index, AFI-PSU subsidies are a fair index: it covers all institutions and it has been maintained for a long period of time. The unquestionable point is that all Chilean universities want to attract this subsidy by inducing the students to postulate to the corresponding university. The reason for these universities' behavior is not only the obvious quantity of money the students can carry to their budgets but also (and this is, in no way, a minor point) the amount of prestige this system brings. In the market of higher education, the institutions do not matriculate all demanding people, instead, as Kirp cleverly points out, "...the "sellers" in this peculiar market, the universities, seek out the most attractive "buyers"- that is, students" (KIRP, 2003).

The estimation for the financial market Chilean universities spans between 1.8 to 2.0 US $\$$ billion (as conjectured by a weekly magazine (DE LA FUENTE; LOPEZ, 2010)) to about 3.0 US\$ billions. We based our last estimate in data from Brunner 2008 and the Consejo Superior de Educación 2010.

The amount of money the AFI distributed in year 2009 was about US\$ 37 million, an amount practically constant during the last decade. From this amount, $98.6 \%$ was captured by universities $(77.1 \%$ for CRUCH universities, $21.5 \%$ corresponds to "private" universities) and the remaining amount to other institutions belonging to the higher education system. The system rewards higher education's institutions which recruit the 27500 students with the highest PAA-PSU scores. These students are ordered into five quintiles. The first quintile defines a per capita "unit". This amount grows in factors of 3, 6, 9 and 12 for the remaining quintiles. Therefore, there are different amounts of money

2 In the nomenclature used on the OECD report (2009), this category is named "indirect public grant". 
per student according to his/her relative position in the national exam. It is to be noted that although the total amount and the number of beneficiaries of this subsidy has been invariable, the stock of students have grown dramatically (THE WORLD BANK, 2009).

From the above mentioned financial amounts, it absolutely clear that the dispute of these talented students is not directly related to money. Prestige is the game.

In the present note, we propose to use the AFI amount of money captured by each university, as a quantitative index of wealth of each institution. Of course, we stress again that the indicators we are using do not pretend to express all the true academic wealth but it would be arguable that it describes this attribute from the student's point of view. We will use it in this described restricted sense. With these preventions, by means of this indicator, we will use well established statistical methods to determine the degree of concentration of academic wealth on the whole Chilean university system.

\section{RESULTS}

The OECD report (2009) establishes that: "The AFI was intended to promote quality by encouraging competition for the best students. In practice it directs public funding to the institutions with established high reputations whose students are most likely to come from better-off families". In this report and other studies there are ample evidence that this subside operates as a mechanism that increase income inequality in prospective university students: better PAA-PSU scores comes mainly from wealthy families students.

We use the statistical data provided by the Ministry of Education in Chile (2010). We start our analysis with the year 1995. Prior to this date some of the present traditional universities did not achieve their present status. We cover eight years of practice with the PAA-test and five years with the PSU-test. Our data excludes CFT, IP and Army academies, institutions also eligible for this state support. In fact, these last institutions receive only around $1 \%$ of the total amount of money and therefore their contribution can be neglected. This choice has the advantage that we compare institutions theoretically comparable.

We depict our results in the form of the Lorenz curve during the considered period of time and in an attempt to better appreciate the differences between different years a semilog plot was constructed (Fig.1a and Fig.1b). The linear Lorenz graph shows a uniform development for all the considered years. On the other side, the semilog graph better resolves the data and it shows a tendency to increase the inequality. Fig. 2 displays the calculated Gini index. 
Figure 1 - a) AFI fraction (Red points: 1995-2003. Black points: 2004-2009), linear scale; b) logarithmic scale

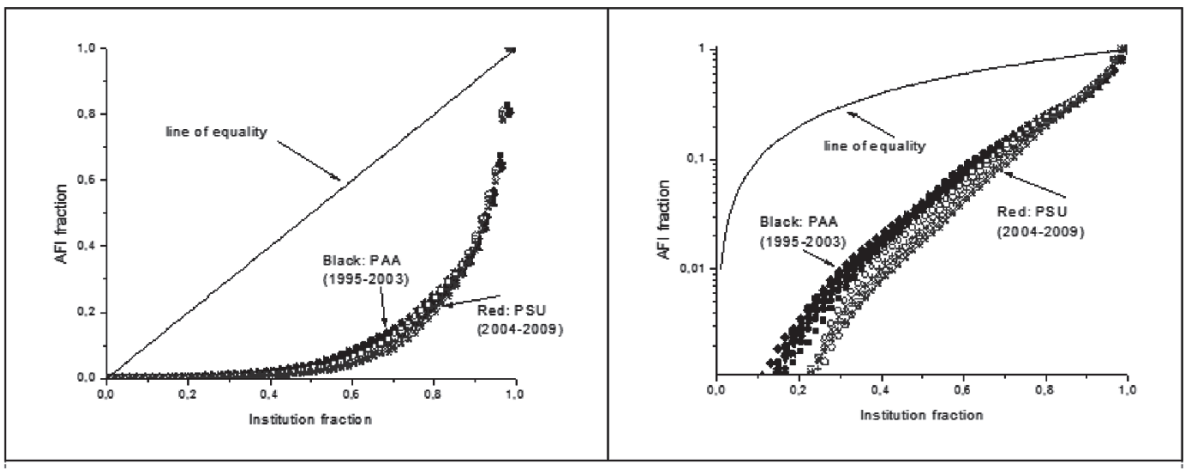

The previous results clearly show that the analysis of equity-inequity based in the behavior of the Gini index, using the AFI-PSU assignations as indicators of income, is invariant in time or, at least, it shows a very slow variation. In other words the established behavior-whatever it means- is permanent in time.

The second conclusion is that the Chilean university system is highly concentrated with a clear bias to "richer" universities. Although it could be questionable the analogy, and only for the sake of comparison, let us quote from the econometric literature related to income distribution, that a Gini coefficient of about 0.2 is characteristic to egalitarian societies (i.e. Finland). USA has an index of about 0.4 and the country with the worse distribution has an index of about 0.6 (THE WORLD BANK, 2005). A recent report of PNUD (PNUD, 2010) informs that in Latin American and Caribbean countries the Gini index ranges between 0.45 and 0.6 .

Similarity, let us mention that -although different in purpose to this paperGini index has been used to measure educational inequality. Thomas, Wang and Fan. (2001) report that Korea has a Gini index of 0.22 and India, 0.69 (data from 1990).

Fig. 2 shows a (small) decrement in the Gini index for the PAA-period and a (small) increment for the PSU-period. Although surprising, the possible reason for this effect could be the fact that in the recent years, there are been an increment in the number of institutions. The newer ones by obvious reasons are not able to capture this subsidy, so increasing the number of institutions inside the first quintile of wealth. Nevertheless, Gini index shows a maximum variation of only 0.054 during the reported period of time. 
Figure 2 - Gini-index. Solid lines show the tendencies

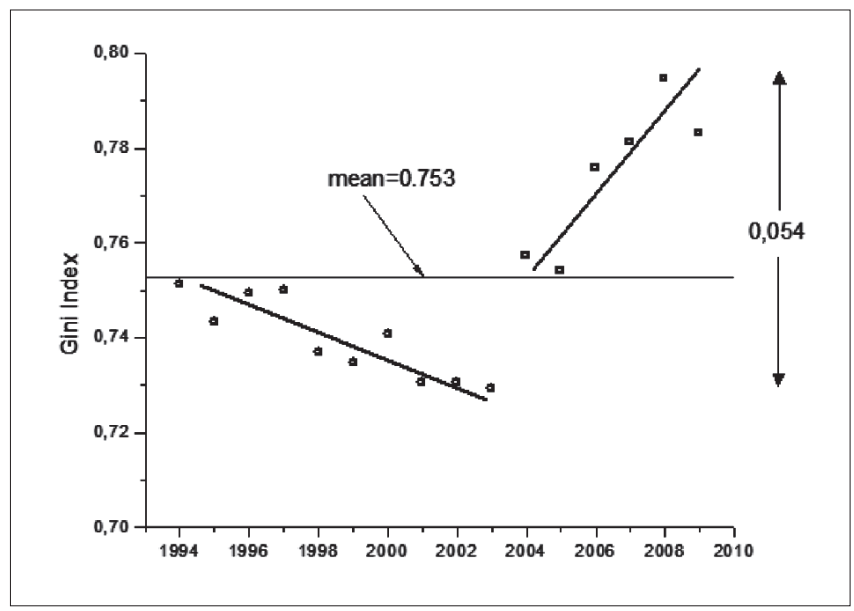

Clearly, an egalitarian wealth distribution is a fair goal for a society with high income (to be equal in poverty is not an ideal state). Is this utopia a valid one for a national system of universities? To our knowledge there is not a univocal answer to these questions. To put it in an ideological context, a liberal scholar would argue that, thanks to the market forces, differentiation between institutions will inevitably appear and, after some transient time, things will evolve to reach a steady state. From the opposite side, it is possible to argue that the government (or some other agency) must assure the quality of the universities; after all, these institutions operate under a common condition (and they use the same name, as established by the Chilean law). Historical conditions suggest that the European system of universities show a more equalitarian situation that their American counterparts. However, times are changing, and the European model is evolving to a liberal one.

Tangentially, although not of minor importance, the fact is that "private" universities do not obtain a significant share of the AFI contribution, thus showing a feeble participation in the total amount of academic wealth.

It is possible to find other measures of "academic wealth". In the Chilean system of higher education there is a national system of institutional accreditation for this kind of institutions (for a detailed account, see CNA-Chile, 2010). In a plain summary the system is a voluntary one. The process certifies organizations in a certain number of areas (management, undergraduate curricula, community insertion, graduate studies and research) and for a certain number 
of years. That is, at the end of each of this process it is obtained two numbers: one gives the temporal extent of accreditation, call it $m$ (years, $0 \leq n \leq 7$ ) and the other gives the number of accredited areas, say, $m(0 \leq m \leq 5)$. There are two mandatory areas (management and undergraduate curriculum) and the organizations may (or may not) apply to other areas as described.

Therefore it is possible to build a composed index: number of years multiplied by number of areas, which may describe the strengths and/or the weakness of each institution (in the nomenclature of the former paragraph: $0 \leq m n \leq 35$ ). In what follow we name this composite index as the "mn index". It is possible to hypothesize that the greater this index, the greater is the "academic wealth" of the university, as perceived by the official accreditation agency. In this way it is possible to correlate this number with the numbers resulting from the AFI distribution. We will use the data provided by Rodríguez (2010) for the year 2009.A simple view of the results depicted in Fig. 3 show that although there is a positive correlation between these two set data, this indicator only show a feeble relationship between these two indexes (the linear regression gives $\left.R^{2}=0.53\right)$.

Figure 3 - AFI assignations 2009 correlated with "mn" factor

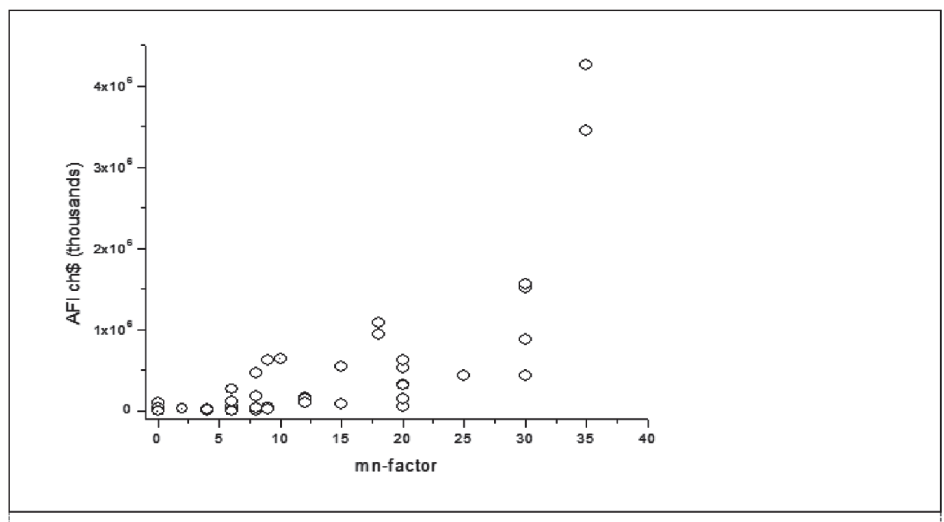

Fig. 4 shows the Lorenz curves for AFI and mn data (2009). Note that Gini index is significantly greater $(0.78)$ than the corresponding mn-factor $(0.50)$. Clearly although the two indicators show a biased system, the students' perception shows a different picture than the official accreditation results. 
Figure 4 - Lorenz curves for mn-index and AFI, year 2009

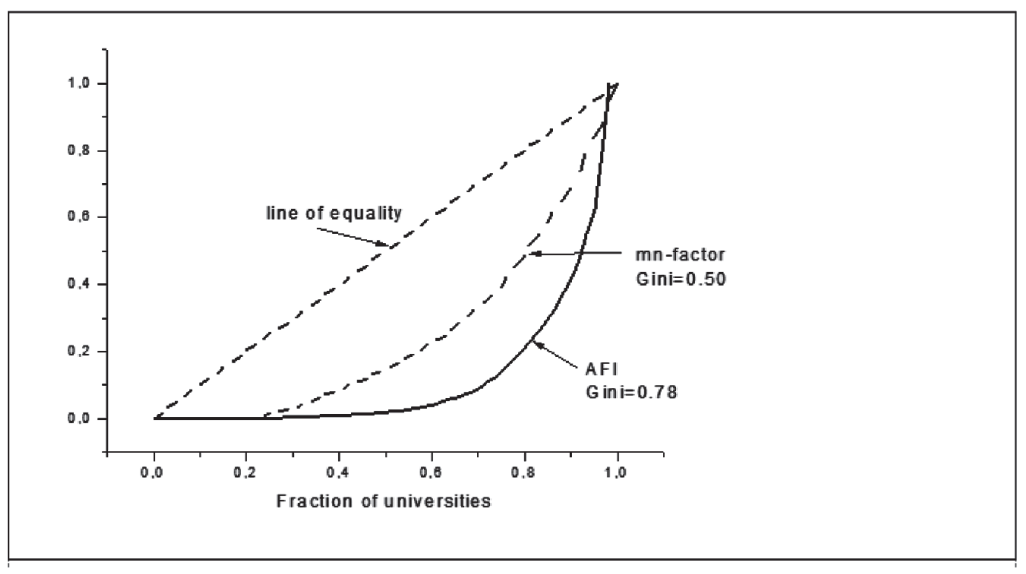

\section{AN UNBALANCED SYSTEM}

With the two indicators we are dealing with, the system is unbalanced. But, why is the system so imbalanced? Although our following arguments will be clearly of a hypothetical nature, they can used as a starting point for further analysis.

\section{a) Size effect}

Is this difference in quality a result of the drastic increase in university students during the years this work considers? It is a notable fact that the year 1996 there was 243082 students inscribed in universities and in 2009 this number increments to an impressive total of 533348 according to the official data of the Consejo Nacional de Educación (2009) (National Council for Education, Chile). An astonishing rate of $119 \%$ ! Studies show that opening of quasi free market for secondary education increments the covertures but it do not improve the quality (for the high school Chilean case see i.e., McEwan and Carnoy 2000; Hsieh and Urquiola 2006). On the other had, a simple reflexion: is it possible to create the necessary faculty in a decade in order to double the number of students? 


\section{b) Marketing}

Currently, the marketing departments of the upper level institutions develop a series of marketing actions in order to capture and negotiate these intellectual "stars". In this game, institutions are "buyers" and students are "sellers". A very peculiar situation indeed!

Although the capture of talented students is a person-to person link, it is undoubting that this micromarketing is based on the prestige of the university "mark" itself. The share market high schools and universities encloses, ranks number third (2007) and fifth (2008) in the total marketing investment in the country (ACHAP-Megatime report, 2009). It would be presumed that the great volume of this marketing activity is aimed to prospective university students.

\section{c) Geographical location}

Continental Chile is very peculiar geographical country. It is a long (2 880 mi) and narrow country (265 mi in its widest width), with a deserted North and an almost Antarctic South. Perhaps this fact favors the extreme concentration in population this country has. In metropolitan Santiago (the capital city) inhabits about $40.2 \%$ of the total country population (datum from 2009, INE-Chile). This concentration is reflected in all aspects of the political geography, including of course the higher education sector. The number of students inscribed for the 2010 PSU-test was a total of 285325 , and $40.2 \%$ belongs to the metropolitan Santiago region (DEMRE, 2010). Some data on concentration appears in Table 1. These results show that Santiago universities, in fact, cover an ample portion of the students. Furthemore, they capture more than its regional percentage.

\section{Table 1 - Geographical higher education concentration at metropolitan Santiago}

\begin{tabular}{c|c|c|c}
\hline $\begin{array}{c}\text { Santiago } \\
\text { Inhabitants/total } \\
\text { country (2009), \% }\end{array}$ & $\begin{array}{c}\text { Registered Santiago } \\
\text { PSU students/total } \\
\text { country (2010), \% }\end{array}$ & $\begin{array}{c}\text { Students living in } \\
\text { Santiago with AFI } \\
\text { assignation/total } \\
\text { country (2010), \% }\end{array}$ & $\begin{array}{c}\text { AFI captured } \\
\text { by Santiago' } \\
\text { universities/total } \\
\text { country, \% }\end{array}$ \\
\hline 40.3 & 40.0 & 50.8 & 57.9 \\
\hline
\end{tabular}

\section{d) Peer effect}

Peer effect is cited in the literature (see i.e. Andrade; MOITA; SILVA, 2009) as an effect that talented students prefer institutions perceived as the best in terms of prestige and taking due account for the quality of their present stu- 
dents. There seems that in this market, brain concentration is a sound capital for the institutions. It is almost an example on the concentration of capital in unregulated markets.

This brief vision of the possible causes of this academic inequality clearly must be analyzed by a deeper research.

\section{FINAL REMARKS}

Let us emphasize a last point. On the ample battery of state subsidies to educational systems, it appears a type of money transfer named "vouchers" in the specialized literature. It is a subsidy to the demand: the favored persons (more strictly his/her family) own the funding and therefore can choose his/ her supplier of education. On a general discussion on the public financing of the education, see i.e., Lott (1987), Wigger and Von Weiszäcker (2001) and Zhang (2009).

However, the AFI subsidy we are dealing with belongs to a different class of rationale. It is supposed that all prospective students has the potential to compete for this reward, and in this sense it is an expression of the (pseudo) "equality in opportunities", but in fact, only the more wealthy students (in income and cultural capital) are the subset that can obtain this stimulus. Different to a voucher, this reward is located to a certain fraction of students and they can negotiate his/her admission to the most prestigious universities. Universities that -mutatis mutanda- buy this talented capital ${ }^{3}$.

Summing up, we have show that the Chilean system of universities shows a high degree of concentration of perceived academic wealth (measured by AFI assignations) consistently in the same group of universities. This characteristic is (almost) constant in time. Also, we have sketched some hypothetical reasons to explain this fact and we build another indicator based the results of the accreditation of the universities. This new indicator itself show inequality (Gini index, 0,52) and could represent the perception of the quality of the institutions as viewed by the official and regulated system of state controls. Notably, it shows a low correlation with the AFI results.

The implications of these facts are open to an analysis of public policies: Is it preferable to have a broad range quality between institutions (high Gini's index) or a quasi equalitarian system (low Gini index)? Surely, the answer must be some "in between" state but at the end, this ideal condition is open to debate.

3 In fact, this mechanism is strongly similar to the procedure some USA's universities enforce to captivate the best "students" for their athletic teams. 


\section{ACKNOWLEDGEMENTS}

The author acknowledges the help and comments of Fabiola Cabrera. Also, the data base management of Lynda Contreras.

\section{REFERENCES}

ACHAP-Megatime Report. 2009. Inversión 2008. Inversión Publicitaria. (2008 Marketing Investment). Disponible en: <www.achap.cl/documentos/ INV_2008.ppt>. Aceso en: jun. 2010.

ANDRADE, E.; MOITA, R. M.; SILVA, C. E. L. Peer effect and competition in higher education. 2009. Disponible en: < virtualbib.fgv.br/ ocs/index.php/sbe/EBE09/paper/viewFile/1004/318>. Aceso en: jun. 2010.

BERNASCONI A.; ROJAS, F. Informe sobre la Educación Superior en Chile: 1980-2003 (Report on Chilean Higher Education: 1980-2003). Santiago, Chile: Editorial Universitaria, 2004.

BRUNNER J. J., G. ELACQUA, A. TILLET, J. BONNEFOY, S. GONZÁLEZ, P. PACHECO; F. SALAZAR. Guiar el Mercado: Informe sobre la Educación Superior en Chile (Guiding the Market: Report on Chilean Higher Education). Santiago, Chile: Universidad Adolfo Ibáñez, 2005. Disponible en: $<$ mt.educarchile.cl/archives 2005/08/chilean_higher. html>. Aceso en: jun. 2010.

BRUNNER J. J. El sistema de educación superior en Chile: un enfoque de economía política comparada (The higher education system in Chile: a comparative political economy approach). Avaliação, Campinas, Sorocaba, v. 13, n. 2, p. 451-486, jul. 2008.

BRUNNER J. J. Mercados, instituciones y políticas en la eduación superior chilena (Markets, institutions and policies in Chilean higher education). Temas, n. 57, p. 52-59, 2009.

CNA - Comisión Nacional de Acreditación. 2010. Disponible en: <www. cnachile.cl>.Aceso en: jun. 2010.

CNE - Consejo Nacional de Educación. 2010. Disponible en: <www. consejo.cl/public/Secciones/seccionestadisticas/estadisticas_home.aspx $>$. Aceso en: jun. 2010. 
CYRENNE P.; GRANT, H. University decision making and prestige: An empirical study. Economics of Education Review, Columbia, v. 28, p. 237248, 2009.

DE LA FUENTE, A., LOPEZ, M.J. Universidades: un mercado bullente (Universities: a boiling market). QuePasa, London, v. 38, p. 47-50, 2010.

DIGDOWISEISO, K. Measuring Gini coefficient of education: the Indonesian case. 2010. Disponible en: $<$ http://mpra.ub.uni-muenchen. de/18965>. Aceso en: jun. 2010.

HSIEH C-T.; URQUILOLA, M. The effects of generalized school choice on achievement and stratification: Evidence from Chile's voucher program. Journal of Public Economics, Berkeley, v. 90, p. 1477- 1503, 2006.

INE - Instituto Nacional de Estadísticas. Compendio Estadístico. 2009. Disponible en: $<\mathrm{http}$ //www.ine.cl/canales/menu/publicaciones/compendio estadistico/pdf/2009/1_2_estadisticas_demograficas.pdf>. Aceso en: jun. 2010 .

LOTH, L. R. Why is education publicly provided? A critical survey. Cato Journal, Washington, v.7, p. 475-501, 1987.

LYNCH K.; O'RIORDAN, C. Inequality in Higher education: a study of class barriers. British Journal of Sociology of Education, Cambridge, v. 19, p. 445-478, 1998.

KIRP, D. Shakespeare, Einstein and the Bottom Line: the marketing of higher education. Cambridge, Massachusetts: Harvard University, 2003.

MCEWAN P. J.; CARNOY, M. The effectiveness and efficiency of private schools in Chile's voucher. Educational Evaluation and Policy Analysis, Washington, v. 22, p. 213-239, 2000.

PNUD. Programa de las Naciones Unidas para el Desarrollo. Informe Regional sobre Desarrollo Humano en América Latina y el Caribe. 2010. Disponible en: $<w w w . i d h a l c-a c t u a r s o b r e e l f u t u r o . o r g>$. Aceso en: jun. 2010.

RAPPAPORT D., BENAVENTE, J. M.; MELLER, P. Rankings de universidades chilenas según los ingresos de sus titulados (Ranking of Chilean universities according to their graduates' income). Central Bank of Chile. Santiago, Chile: Working Paper n. 306, 2004. Disponible en: <www. bancocentral.cl>. Aceso en: jun. 2010. 
RODRÍGUEZ, E. Rendición de Cuenta Pública de la Comisión Nacional de Acreditación. 2009 (Public Report of the Chilean Accreditation Agency). Santiago, Chile: Comisión Nacional de Acreditación, 2009.

CHILE. MINISTERIO DE EDUCACIÓN DE CHILE. 2005. Disponible en: $<$ http://ww.mineduc.cl/superior $>$. Aceso en: jun. 2010.

THE WORLD BANK. OECD and the International Bank Reconstruction and Development. 2009. Reviews of National Policies for Education:

Tertiary Education in Chile.Disponible en: <www.oecd.org/document/57/0,3 343,en_2649_39263238_42223801_1_1_1_1,00.html>. Aceso en: jun. 2010. THE WORLD BANK. 2005. Disponible en: <www.worldbank.org/data>.

THOMAS, V.; WANG, Y.; FAN, X. Measuring coefficients of inequality: Gini coefficients of education, Policy Research Working Papers. No. 2525, 2001. World Bank Institute. Disponible en: <citeseerx.ist.psu.edu/viewdoc/ download?doi=10.1.1.17.3253\&rep=rep1\&type=pdf $>$. Aceso en: jun. 2010.

UNIVERSIDAD DE CHILE. Departamento de Evaluación, Registro y Medición (DEMRE). 2010. Compendio Estadístico. Proceso de Admisión 2010 (Statistics. Admission process 2010). Disponible en: <www.demre.cl/ text/pdf/p2010/Compendio\%202010.pdf>. Aceso en: jun. 2010.

WIGGER B. J; VON WEITZSÄCKER, R. K. Risk, Resources, and education: public versus private finance of higher education. Working paper of the International Monetary Fund, WP/99/174, 1999, n. 48, p. 547-560, 2001.

WÖRNER C. H. El aporte fiscal directo (1993-2008) para las universidades del Consejo de Rectores de Universidades Chilenas (Direct state subsidy (1993-2008) for universities belonging to the Consejo de Rectores de Universidades Chilenas. Calidad en la Educación, Santiago, n .8, p. 179186, jul. 2009.

ZHANG L. A value-added estimate of higher education quality of US states. Education Economics, Lancaster, v. 17, p. 469-489, 2009. 


\section{APPENDIX}

\section{Some Statistical Preliminaries on the Gini index}

The degree of inequality of a certain variable (AFI money in the present case) is described by the Lorenz curve. If we have an ordered vector $X=\left(x_{p}\right.$, $\left.x_{2}, \ldots, x_{N}\right)$ in a $N$-dimensional space, the Lorenz curve (strictly a polygon) is defined by the set of points $\left(h / N, L_{h} / L_{N}\right)$, where $h=0,1,2, \ldots, N ; L_{0}=0$; and $L_{h}=\sum_{i=1}^{h} x_{i}$. By definition, this polygon goes from the origin to the point $(1,1)$. In this diagram we can also draw the locus of the points $(i, i) i \in(0,1)$. This last line is called the "line of perfect equality". The comparison between the Lorenz curve and the line of equality gives us a measure of the degree of concentration of the corresponding variable.

In order to have a single parameter for the degree of inequality, the so called, Gini coefficient is used (Gini, 1921). For this purpose, the difference between the area covered by the 45 degree line (line of equality) and the area under the Lorenz curve is calculated. The ratio between this difference and the whole area of the 45 degree triangle, gives the Gini coefficient. The Gini coefficient runs between zero (perfect equality) to one (absolute inequality). 